\title{
Levels of Serotonin in the Hemolymph of Aplysia Are Modulated by Light/Dark Cycles and Sensitization Training
}

\author{
Jonathan Levenson, ${ }^{1}$ John H. Byrne, ${ }^{2}$ and Arnold Eskin ${ }^{1}$ \\ ${ }^{1}$ Department of Biology and Biochemistry, University of Houston, Houston, Texas 77204-5513, and 2Department of \\ Neurobiology and Anatomy, University of Texas-Houston Medical School, Houston, Texas 77225
}

Serotonin (5-hydroxytryptamine, 5-HT) modulates the behavior and physiology of both vertebrate and invertebrate animals. Effects of injections of 5-HT and the morphology of the serotonergic system of Aplysia indicate that 5-HT may have a humoral, in addition to a neurotransmitter, role. To study possible humoral roles of 5-HT, we measured 5-HT in the hemolymph. The concentration of $5-\mathrm{HT}$ in the hemolymph was $\sim 18$ $\mathrm{nm}$, a value close to previously reported thresholds for eliciting physiological responses. The concentration of 5-HT in the hemolymph expressed a diurnal rhythm. In addition, electrical stimulation that leads to long-term sensitization significantly increased levels of 5-HT in the hemolymph during training, 1.5 $\mathrm{hr}$ after training, and $24 \mathrm{hr}$ after training. Moreover, levels of 5-HT in the hemolymph were significantly correlated with the magnitude of sensitization. The half-life of an increase in 5-HT in the hemolymph was $\sim 0.5 \mathrm{hr}$. Therefore, the persistent in-

Serotonin influences behavioral state in a number of vertebrates and invertebrates (for review, see Edwards and Kravitz, 1997). In Aplysia, 5-HT is involved in mediating sensitization of defensive withdrawal reflexes (Brunelli et al., 1976; Bernier et al., 1982; Klein et al., 1982; Walters et al., 1983; Glanzman et al., 1989; Hammer et al., 1989; Schacher et al., 1990; Trudeau and Castellucci, 1993; Emptage et al., 1996) and regulating the phase of the ocular circadian rhythm (Corrent and Eskin, 1982), cardiac output (Liebeswar et al., 1975; Sawada et al., 1984), muscle tone (Weiss et al., 1975; Cooper et al., 1989; McPherson and Blankenship, 1992), bag cell afterdischarge (Kaczmarek et al., 1978), locomotor activity (Mackey and Carew, 1983), swimming behavior (Parsons and Pinsker, 1989; McPherson and Blankenship, 1991; Laurienti and Blankenship, 1997), and the sensitivity of photoreceptors and mechanoreceptors (Eskin and Maresh, 1982; Billy and Walters, 1989). Feeding behavior is also modulated by 5-HT released by the metacerebral cell (Weiss et al., 1975; Kupfermann et al., 1979; Rosen et al., 1983). Moreover, activity of the serotonergic metacerebral cell directly correlates with central arousal in Aplysia (Kupfermann and Weiss, 1982).

Several lines of evidence indicate that 5-HT may have a humoral role in Aplysia. 5-HT has widespread physiological effects,

\footnotetext{
Received Feb. 4, 1999; revised June 7, 1999; accepted June 29, 1999.

This work was supported by grants from the National Institutes of Health (MH41979 and NS28462 to A.E. and NS19895 to J.H.B.). We thank R. Fernandez, S. Hattar, K. Herynk, G. Kelly (Marinus, Inc.), G. Patterson, and J. Selcher for technical assistance.

Correspondence should be addressed to Arnold Eskin, University of Houston, Department of Biology and Biochemistry, 3201 Cullen Boulevard, HSC 401, Houston, TX 77204-5513.

Copyright (C) 1999 Society for Neuroscience $\quad 0270-6474 / 99 / 198094-10 \$ 05.00 / 0$
}

crease of 5-HT in the hemolymph $24 \mathrm{hr}$ after sensitization training indicates that training caused a long-lasting increase in the release of 5-HT. This long-lasting increase in 5- HT in the hemolymph was blocked by treatment with an inhibitor of protein synthesis during training. Based on the levels of 5-HT in the hemolymph and its regulation by environmental events, we propose that $5-\mathrm{HT}$ has a humoral role in regulation of the behavioral state of Aplysia. In support of this hypothesis, we found that increasing levels of 5-HT in the hemolymph led to significant alterations in feeding behavior. Increasing levels of 5-HT during the daytime when they were normally low increased the latency to assume feeding posture from daytime to nighttime values.

Key words: Aplysia; mollusk; serotonin; hemolymph; sensitization; diurnal rhythms; learning; feeding; emetine and injections of 5-HT into the hemocoel increase the number and frequency of a variety of spontaneous behaviors for a short period of time (Palovcik et al., 1982; Mackey and Carew, 1983; Parsons and Pinsker, 1989). Also, the projections of serotonergic fibers indicates that 5-HT may be released into the hemocoel. For example, serotonergic fibers innervate the aorta and other arteries, and also form a basket around the eye (Takahashi et al., 1988; Alevizos et al., 1989; Skelton and Koester, 1992).

As a first step to further examine the possible humoral role of 5-HT in Aplysia, we investigated whether 5-HT was present in the hemolymph and, if so, whether its levels were regulated. In this study, we demonstrate that 5-HT is present in the hemolymph of Aplysia and that its concentration is near threshold for a number of physiological effects of 5-HT. We show that levels of 5-HT in the hemolymph are regulated by light/dark cycles and by electrical stimulation that leads to long-term sensitization. Furthermore, we show that perturbations of 5-HT in the hemolymph affect aspects of appetitive feeding behavior.

\section{MATERIALS AND METHODS}

Aplysia californica (100-150 gm) were obtained from Marinus (Long Beach, CA). Animals were maintained in Instant Ocean (Aquarium Systems, Mentor, $\mathrm{OH}$ ) at $15^{\circ} \mathrm{C}$ under a $12 \mathrm{hr}$ light/dark (LD) cycle. Animals were allowed to adapt to laboratory conditions for $3 \mathrm{~d}$ before use except in the experiment measuring the 5-HT levels of animals just after their arrival in the laboratory. Animals used for sensitization training were kept in individual plastic cages in recirculating seawater tanks. They were fed dried seaweed every 2-3 d. All other animals, except those used in feeding latency experiments (described below), were placed directly in recirculating seawater tanks (100 gal) and fed romaine lettuce every $2-3$ d. Animals were housed in constant darkness (DD) by transfer to a $30 \mathrm{gal}$ recirculating seawater tank kept in light-tight housing. 
Measurements of levels of 5-HT in hemolymph of Aplysia living in the field were performed on animals $(100-150 \mathrm{gm})$ captured from tidal pools along the coast of Southern California and immediately sampled (see below). All animals were captured and sampled during the day in mid-October. Conditions at the site of capture were calm, and water temperature was $\sim 19^{\circ} \mathrm{C}$.

To measure levels of 5-HT in the hemolymph of animals immediately after arrival into the laboratory, animals were removed from original shipping containers and equilibrated for 15-30 min. During this equilibration, animals remained in individually sealed plastic bags, which were placed in seawater tanks maintained at $15^{\circ} \mathrm{C}$. After equilibration, bags were opened, and hemolymph was immediately sampled (see below). Animals were then fed (lettuce), transferred to individual plastic cages, and maintained under standard environmental conditions (see above).

Long-term sensitization produced by electrical stimulation was performed as previously described (Goldsmith and Byrne, 1993; Cleary et al., 1998). Briefly, animals were administered 4 blocks of 10 shocks over $1.5 \mathrm{hr}$ to one randomly selected side of the animal. Each shock consisted of a $500 \mathrm{msec}$ pulse of $60 \mathrm{~mA}$ applied to the body wall. Release of ink and opaline, defensive secretions caused by noxious stimuli, were reliably elicited with this training protocol (Goldsmith and Byrne, 1993). Baseline hemolymph samples were withdrawn $0.5 \mathrm{hr}$ before the first stimulus. Other samples were withdrawn at times indicated in the text. Single animals were sampled multiple times during training (as noted in Results), but in all other cases hemolymph was sampled only once from an animal. Control animals did not receive electrical stimulation, but were handled identically to sensitized animals in all other respects.

Siphon withdrawal duration was measured, and hemolymph was subsequently sampled to correlate changes in duration of siphon withdrawal with changes in levels of 5-HT in the hemolymph. Teflon-coated silver wire electrodes were implanted into the posterior region of the tail, as previously described (Scholz and Byrne, 1987; Goldsmith and Byrne, 1993), for delivery of electrical stimuli (20 msec, AC shock). Baseline hemolymph samples were withdrawn $30 \mathrm{~min}$ before threshold determination. Several test stimuli were administered to determine threshold current required for eliciting siphon-withdrawal. Siphon withdrawal was assessed at two-times the threshold current required to elicit the reflex. Immediately after determining the baseline siphon withdrawal duration for each side, electrical stimulation was administered over one side of the body wall as above. Siphon withdrawal duration was measured $24 \mathrm{hr}$ after the end of electrical stimulation, and then hemolymph was withdrawn immediately afterward. Hemolymph was withdrawn from the side of the animal that did not receive electrical stimulation. Withdrawal of hemolymph did not induce long-term sensitization. Control animals did not receive electrical stimulation, but were handled identically to sensitized animals in all other respects. The experimenter who measured siphon withdrawals was blind to whether the animals received electrical stimulation and the side from which hemolymph was withdrawn.

To measure the half-life of 5-HT in the hemolymph of animals that were electrically stimulated once 5-HT was elevated, individual Aplysia were sensitized by the standard long-term training protocol and then placed in 31 of seawater that contained $250 \mu \mathrm{M} 5$-HT (creatine-sulfate complex; Sigma, St. Louis, MO) for $0.5 \mathrm{hr}$ (Alberini et al., 1994). Hemolymph was sampled before, immediately after, and then $0.5,1$, and $6 \mathrm{hr}$ after treatment. Animals were only sampled once during this experiment. Sensitized animals were used in this experiment because the turnover of 5-HT or its diffusion through the skin might be altered by the training procedure.

Collection of hemolymph from animals used in this study was performed using the following protocol. Hemolymph samples $(0.5 \mathrm{ml})$ were withdrawn from animals using a sterile 16 gauge needle and $1 \mathrm{cc}$ syringe. Hemolymph was withdrawn from the animal at a level between the rhinophores and parapodia near the foot. Care was taken to minimize trauma to the animal. Withdrawal of hemolymph only required $\sim 10 \mathrm{sec}$ of handling. In addition, removal of hemolymph only elicited inking in $10 \%$ of the animals used in this study. Subsequent samples of hemolymph from animals indicates that withdrawal of hemolymph did not produce elevation of 5-HT in the hemolymph.

Hemolymph was centrifuged at $4^{\circ} \mathrm{C}$ for 2 min to pellet hemocytes. Previous studies have shown that the hemocytes of various invertebrates, including Aplysia, contain 5-HT (Stefano et al., 1989; Ottaviani and Cossarizza, 1990; Ottaviani et al., 1992; Levenson and Eskin, unpublished observations). Centrifugation did not elicit release of 5-HT from Aplysia hemocytes, because the level of 5-HT measured from centrifuged hemolymph was nearly identical to the level measured from hemolymph diluted with isotonic $\mathrm{MgCl}_{2}$ (180 mm final concentration) or hemolymph that was passed through a $0.22 \mu \mathrm{m}$ filter (data not shown). Cell-free hemolymph was aliquoted, immediately frozen in liquid $\mathrm{N}_{2}$, and stored at $-80^{\circ} \mathrm{C}$. Assays were always performed within $5 \mathrm{~d}$ of collection of hemolymph. 5-HT was measured using a commercially available ELISA (ICN Biochemicals, Costa Mesa, CA). Hemolymph was processed as plasma according to the manufacturer's protocol. After acylation, the resulting solution was diluted with $200 \mu$ l of assay buffer. During processing, hemolymph was exposed to $14 \%$ acetone to precipitate proteins. This treatment should denature any proteins that may bind 5-HT. Thus, total 5-HT in the hemolymph was measured in all of our assays.

Several control experiments were done to verify that the ELISA was valid, because the primary antiserum used actually binds to $N$-acyl-5-HT. Hemolymph that was not exposed to the acylation reagent did not have detectable levels of 5-HT. No 5-HT was present in seawater that had been exposed to acylation. Moreover, the ELISA could accurately measure known amounts of 5-HT added to seawater or hemolymph (data not shown).

The role of protein synthesis in the long-lasting increase in hemolymph 5-HT caused by electrical stimulation was assessed via injection of emetine into the intact animal. Baseline hemolymph samples were withdrawn from animals $0.5 \mathrm{hr}$ before receiving an injection of emetine. Animals were injected with $1 \mathrm{ml}, 9 \mathrm{~mm}$ emetine [dihydrochloride; Sigma; dissolved in buffered-filtered seawater (BFSW) with 3\% ethanol] per 140 $\mathrm{gm}$ body weight $30 \mathrm{~min}$ before electrical stimulation. Injections were estimated to yield $\sim 100 \mu \mathrm{M}$ emetine in the hemolymph, assuming $65 \%$ of the weight of the animal is hemolymph. This concentration was sufficient to significantly inhibit protein synthesis (see Results; Schwartz et al., 1971; Castellucci et al., 1986; Montarolo et al., 1986). Animals injected with emetine responded to electrical stimulation similar to control animals; copious amounts of ink and opaline were secreted, and animals withdrew from the site of shock. Animals injected with emetine became flaccid near the site of injection, but appeared to recover $\sim 3-4 \mathrm{hr}$ after injection. Control animals received a vehicle injection (3\% ethanol in BFSW) in place of emetine. The vehicle did not appear to affect behavior and/or muscle tone. Electrical stimulation was performed as described above. Hemolymph was collected $24 \mathrm{hr}$ after the end of electrical stimulation.

The effect of emetine injections on protein synthesis was assayed by measuring incorporation of $\left[{ }^{3} \mathrm{H}\right]$ leucine into protein in both pleuralpedal and abdominal ganglia as previously described (Raju et al., 1991). In each experiment, two experimental animals were injected with emetine, and two control animals were injected with the vehicle (as above). This experiment was repeated three times. Thirty minutes after injection, pleural-pedal and abdominal ganglia were removed and exposed to $\left.40 \mu \mathrm{Ci} / \mathrm{ml} \mathrm{[}{ }^{3} \mathrm{H}\right]$ leucine $(1 \mathrm{mCi} / \mathrm{ml}$; ICN Biochemicals $)$ in BFSW for $1 \mathrm{hr}$ at $15^{\circ} \mathrm{C}$. After exposure to leucine, ganglia were rinsed 6 times with ice-cold BFSW, blotted dry, and frozen in liquid $\mathrm{N}_{2}$. Ganglia were homogenized, and incorporation of leucine into protein was measured as TCA-precipitable counts. This value was normalized to total counts in the homogenate to adjust for differences in uptake of leucine by the ganglia.

Latency to feeding posture was measured following the technique of Kupfermann (1974). After adaptation to the laboratory, animals were fed to satiation with dried seaweed (Kupfermann, 1974), housed in individual plastic cages, and fasted for $5 \mathrm{~d}$. On the fifth day, latency to feeding posture was tested with a piece of seaweed $\sim 2.5 \mathrm{~mm}^{2}$ in area and $0.25 \mathrm{gm}$ in weight. Animals were only included in this study that had an initial behavioral state of 0 or 1, as defined by Kupfermann (1974), just before experimentation. The 0 and 1 states are characterized by an immobile animal. Rhinophores were brushed with a piece of seaweed, and the seaweed was then kept in the seawater near its surface. Latency to feeding posture was designated as the time elapsed between brushing the rhinophores with seaweed and the display of characteristic "heads-up feeding posture" (Kupfermann, 1974). Latencies measured at night, zeitgeber time 18 (ZT18), were performed under dim red light. Experimental animals received an injection of $1 \mathrm{ml}, 3 \mu \mathrm{M}$ 5-HT (hydrochloride; Sigma) per $150 \mathrm{gm}$ body weight, $20 \mathrm{~min}$ before testing feeding latency. These injections increased levels of 5-HT in the hemolymph within $5 \mathrm{~min}$ to $25.8 \pm 4.9 \mathrm{nM}$, a 5 -HT level normally seen at night. Control animals received an equivalent injection of seawater. All feeding experiments were performed blind. Specifically, the investigator responsible for measuring feeding latency was different from the investigator responsible for injection of 5-HT.

Analysis of 5-HT from animals versus time spent in the laboratory was 


\begin{tabular}{lll}
\hline \multicolumn{2}{l}{ Table 1. Thresholds of physiological responses to 5-HT } & \\
Phenomenon & Threshold (nM) & Reference \\
\hline Cardioacceleration & $0.1-1$ & Liebeswar et al., 1975 \\
Potentiation of ARC contraction & 1 & Weiss et al., 1975 \\
Potentiation of ERG & $10-100$ & Eskin and Maresh, 1982 \\
Phase-shifting of ocular circadian rhythm & $10-100$ & Corrent and Eskin, 1982 \\
Inhibition of spontaneous activity in the eye & $10-100$ & Corrent et al., 1982 \\
Body wall relaxation & $10-100$ & Cooper et al., 1989 \\
Inhibition of R15 bursting & $20-100$ & Drummond et al., 1980a \\
Inhibition of afterdischarge & 125 & Kaczmarek et al., 1978 \\
Facilitation of sensory-motor synapse & 1000 & Brunelli et al., 1976 \\
Induction of swimming behavior & 10,000 & Parsons and Pinsker, 1989
\end{tabular}

performed with a paired, Student's $t$ test. Time-dependent changes, after electrical stimulation and the effect of emetine on the $24 \mathrm{hr}$ increase in 5-HT were analyzed via two-way ANOVA. Elevation of 5-HT in the hemolymph and rhythms in levels of 5-HT were analyzed for significance using one-way ANOVA. The relationship between duration of siphon withdrawal and the magnitude of increase in hemolymph 5-HT was analyzed via product-moment correlation. Feeding latency at midday and midnight, and after 5-HT injection was analyzed using a Wilcoxon two-sample test. All post hoc analyses were performed using the T-method of unplanned comparisons among means (Sokal and Rohlf, 1995). Statistical significance for all tests was set at $p \leq 0.05$.

\section{RESULTS}

The mean level of 5-HT in the hemolymph during the day taken from Aplysia $\geq 3 \mathrm{~d}$ after their arrival to the laboratory was $18.0 \pm$ $0.6 \mathrm{~nm}(\mathrm{SEM} ; n=117)$, and is comparable to the mean level of 5 -HT in the hemolymph measured from animals in the field $(16.7 \pm 1.3 \mathrm{~nm} ; n=17)$. Interestingly, this value is also close to the level of 5-HT in the hemolymph of another mollusc, Helix (Cardot, 1971). This level of 5-HT in the hemolymph of Aplysia is close to threshold values for a number of physiological responses (Table 1).

Initially, animals were sampled immediately (15-30 $\mathrm{min}$, between 10:00 A.M. and 12:00 P.M.) and $3 \mathrm{~d}$ after arrival into the laboratory, a time at which animals are normally used in experiments. The levels of 5-HT in the hemolymph of animals that had just arrived were significantly elevated relative to levels observed after animals had been in the laboratory for $3 \mathrm{~d}$ (Fig. $1 ; t=5.32$; $\mathrm{df}=7 ; p<0.001)$. Levels of 5-HT in the hemolymph did not appear to decrease further after animals had been in the laboratory for $>3 \mathrm{~d}$ (data not shown). The decrease in 5-HT with time in the laboratory suggested that levels of 5-HT in the hemolymph may be regulated by environmental stimuli and be indicative of the state of the animal. Moreover, this observation indicates that animals should be equilibrated in the laboratory before performing behavioral or cellular studies. Several factors may have contributed to the increase in hemolymph 5-HT during shipment of the animals. Animals arrived in the laboratory after approximately one half day of travel, during which they were maintained in cold seawater $\left(\sim 4^{\circ} \mathrm{C}\right)$ in dark, styrofoam boxes. Some possible factors that might contribute to the elevated 5-HT include stress caused by water temperature, handling, or being held in darkness for a long period of time (see Fig. 3). Further experiments are required to determine which of these factors, or others, might be responsible for this change.

\section{Diurnal rhythm of 5-HT}

Aplysia have circadian locomotor rhythms, and 5-HT plays an important role in regulation of ocular circadian pacemakers in

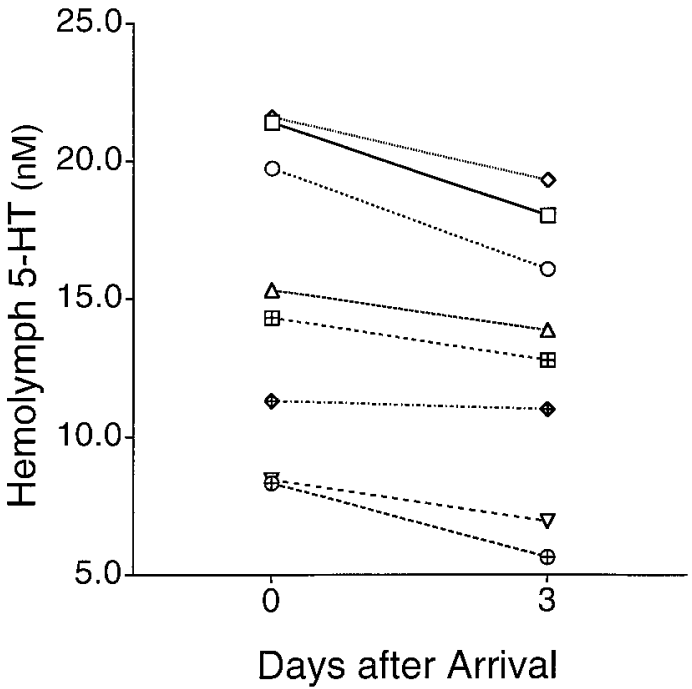

Figure 1. Levels of 5-HT in the hemolymph decrease with time after arrival in the laboratory. Concentration of 5-HT in the hemolymph is plotted as a function of time spent in the laboratory for individual animals. Hemolymph was sampled immediately after arrival at the lab and $3 \mathrm{~d}$ afterward. There was a significant decrease in 5-HT during this period.

Aplysia (Jacklet, 1969; Strumwasser, 1973; Kupfermann, 1974; Lickey et al., 1977; Corrent and Eskin, 1982; Corrent et al., 1982; Eskin and Maresh, 1982; Colwell, 1990). Therefore, we investigated whether the concentration of 5-HT in the hemolymph varied with respect to time of day. Hemolymph was sampled from individual animals once at various times throughout a complete photoperiod. Levels of 5-HT in the hemolymph were significantly affected by light/dark cycles (Fig. $2 ; F=3.54$; df $=47 ; p<0.01$ ). The average concentration of 5 -HT $(18.0 \pm 1.2 \mathrm{~nm}$; average of samples from ZT1-ZT12) in the hemolymph during the day was significantly $(t=4.53$; df $=6 ; p<0.0001)$ lower than the average value at night $(24.4 \pm 0.7 \mathrm{nM}$; average of samples from ZT15-ZT24).

To determine whether changes in the levels of 5-HT observed in a light/dark cycle were under control of a circadian pacemaker, hemolymph was sampled in another experiment from individual animals placed in constant darkness. In these animals, no significant temporal variation of 5-HT in the hemolymph was observed (Fig. 3; $F=0.38$; df $=35 ; p>0.9$ ). The mean concentration of 5-HT in the hemolymph from animals in DD $(25.1 \pm 0.7 \mathrm{nM})$ was similar to levels seen at night in the LD experiment $(24.4 \pm 0.7$ 


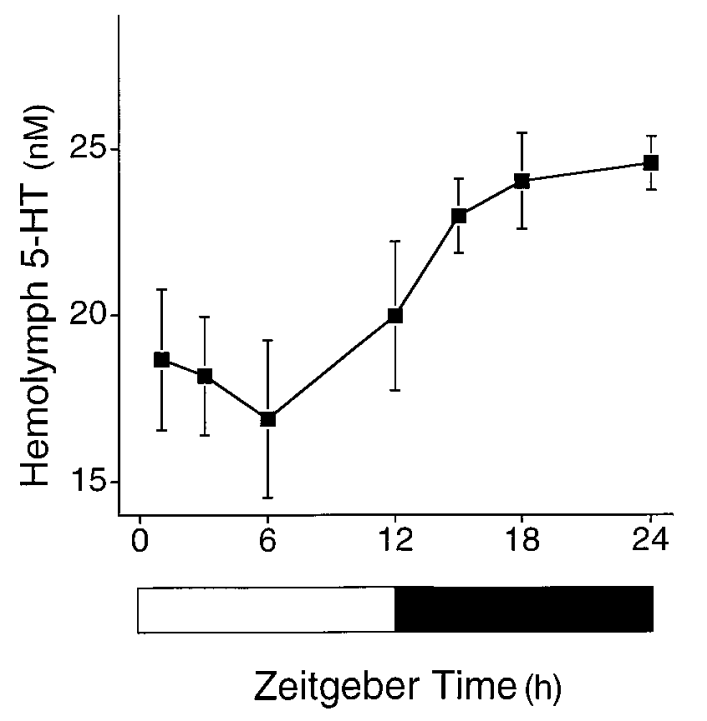

Figure 2. Concentration of 5-HT in the hemolymph is regulated by light/dark cycles. Concentration of 5-HT in the hemolymph is plotted as a function of time of day. Hemolymph was sampled one time from each animal maintained in $12 \mathrm{hr}$ LD cycle. Five to eight animals were sampled at each time point. ZT0 is dawn, ZT12 is dusk. The concentration of 5-HT shows significant variation as a function of time of day. Error bars indicate SEM.

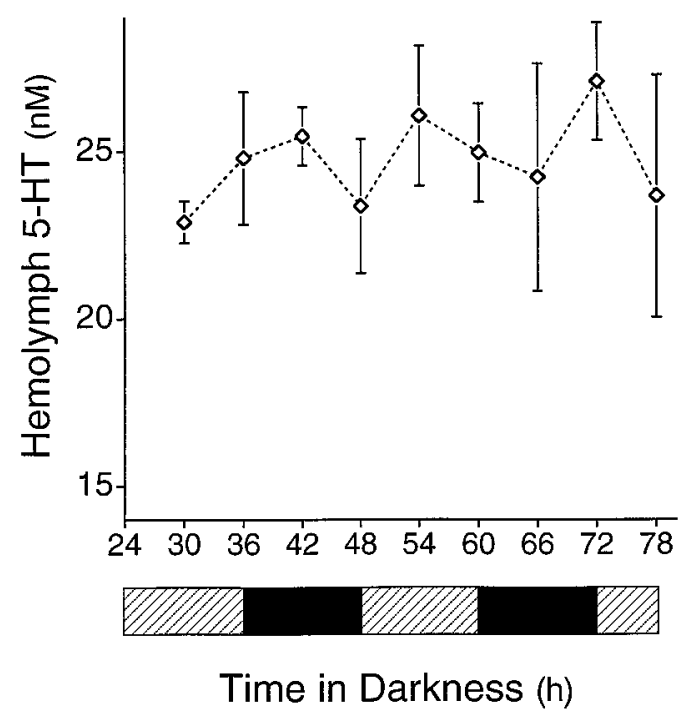

Figure 3. Concentration of 5-HT in the hemolymph does not change when animals are kept in constant darkness. Each animal was sampled only once. No significant variation was seen in the concentration of 5-HT in the hemolymph. In this experiment, 5-HT remained near the nighttime levels that were observed when animals were maintained under a light/dark cycle (Fig. 2). Four animals were sampled at each time point.

$\mathrm{nM})$. This finding indicates that the rhythm of 5-HT observed in LD is caused by light decreasing levels of 5-HT in the hemolymph. Light could lower levels of 5-HT in the hemolymph by affecting levels of enzymes involved in 5-HT biosynthesis. A similar mechanism explains the inhibition of melatonin production by light in the mammalian pineal (Deguchi and Axelrod, 1972; Klein and Weller, 1972; Moore and Klein, 1974). Alternatively, light could modulate the activity of serotonergic neurons to decrease their release of 5-HT, light could inhibit enzymes in-

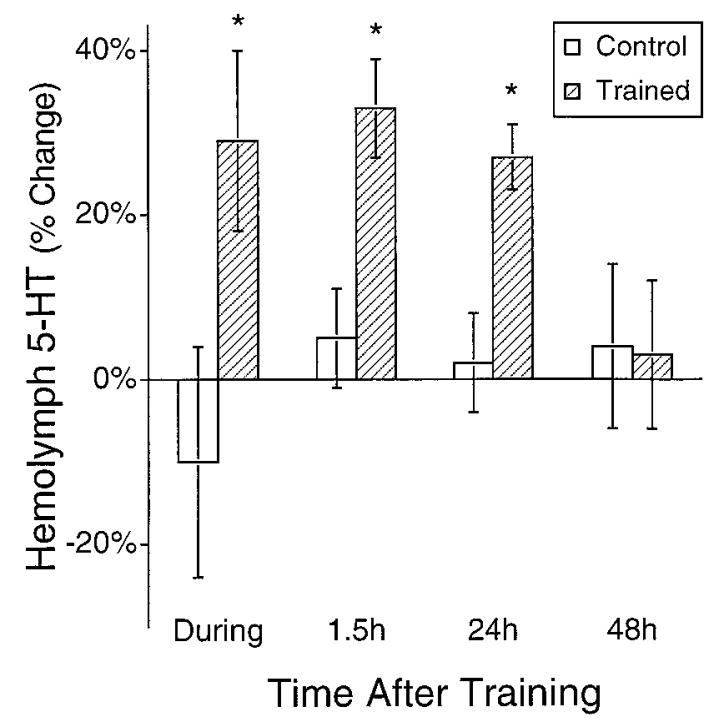

Figure 4. Electrical stimulation elevated 5-HT in the hemolymph during, 1.5 , and $24 \mathrm{hr}$ after stimulation. Concentrations of 5-HT in the hemolymph of experimental animals sampled during, 1.5, 24, or $48 \mathrm{hr}$ after the end of electrical stimulation are plotted relative to the value of 5-HT for each animal $0.5 \mathrm{hr}$ before initiation of stimulation. Control animals were handled exactly as animals that were trained, with the exception that control animals did not receive any electrical stimulation. Four hemolymph samples were taken during training; individual values were averaged to yield a concentration of 5-HT in the hemolymph during training. Individual hemolymph samples were taken $1.5,24$, and $48 \mathrm{hr}$ after training from individual animals that had not been previously sampled. In this and subsequent illustrations, an asterisk indicates a significant ( $p \leq$ $0.05)$ difference relative to control values.

volved in 5-HT degradation, or light could increase renal clearance of 5-HT.

\section{Effect of electrical stimulation on 5-HT in the hemolymph}

Sensitization in Aplysia appears to be mediated, at least in part, via 5-HT. Application of 5-HT mimics many of the effects produced by electrical stimulation that produces sensitization (Brunelli et al., 1976; Bernier et al., 1982; Klein et al., 1982; Walters et al., 1983; Hammer et al., 1989; Schacher et al., 1990; Emptage and Carew, 1993; Trudeau and Castellucci, 1993; Emptage et al., 1996; Zhang et al., 1997), and serotonergic neurons appear to be necessary for sensitization (Glanzman et al., 1989). We investigated whether electrical stimulation would release 5-HT and subsequently increase levels of 5-HT in the hemolymph. Electrical stimulation consisted of 4 blocks of 10 shocks to one side of the animal, with $0.5 \mathrm{hr}$ between each block of shocks. Hemolymph was collected $0.5 \mathrm{hr}$ before stimulation and 1 min after each block of stimulation. Changes in levels of 5-HT in the hemolymph are expressed relative to the level of 5-HT measured $0.5 \mathrm{hr}$ before training. Electrical stimulation significantly elevated levels of 5-HT in the hemolymph (Fig. 4; $F=21 ; \mathrm{df}=65 ; p<0.0001)$. Post hoc analysis indicated that 5-HT was significantly elevated during training [Fig. 4; minimum significant difference (MSD; Sokal and Rohlf, 1995) $=15 \% ; p<$ 0.05]. In addition, an increase in the level of 5-HT in the hemolymph was seen 1.5 and $24 \mathrm{hr}$ after electrical stimulation, however no significant increase of 5-HT in the hemolymph was seen $48 \mathrm{hr}$ after electrical stimulation (Fig. 4).

If the increase in 5-HT in the hemolymph was related to the behavioral sensitization caused by noxious stimulation of the 


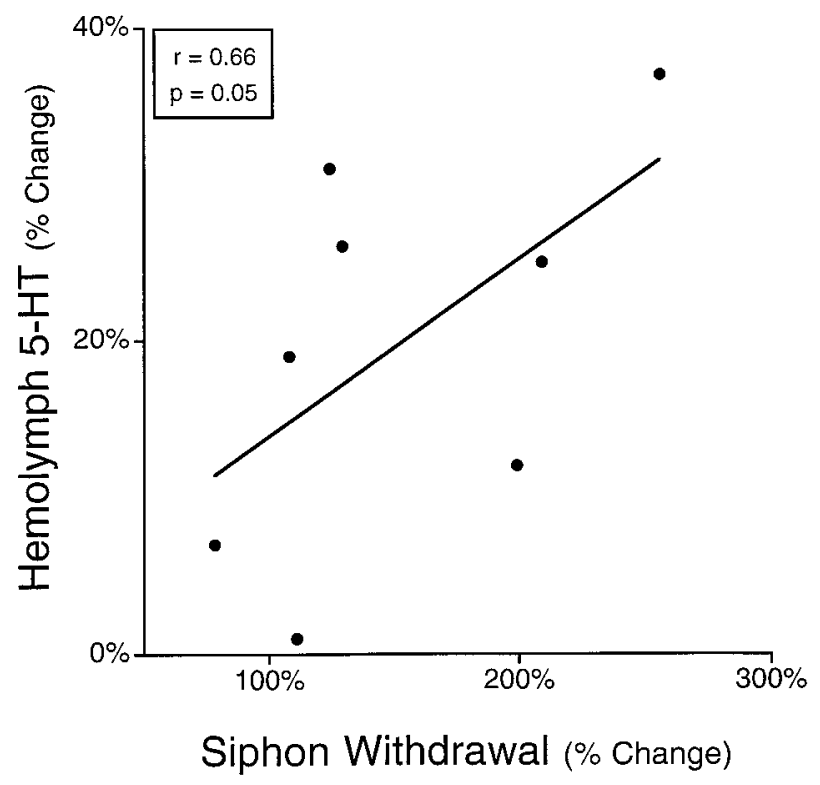

Figure 5. Increases in the duration of siphon withdrawal produced by electrical stimulation were correlated with increases in 5-HT in the hemolymph. Animals were electrically stimulated, and $24 \mathrm{hr}$ later, 5-HT in the hemolymph was measured after determination of the duration of siphon withdrawal. Behavioral changes were significantly correlated with changes in levels of 5-HT in the hemolymph. Measurement of siphon withdrawal did not lead to the elevation of 5-HT in the hemolymph because electrical stimulation alone without behavioral measurement also led to elevation of 5-HT in the hemolymph (see Fig. 4).

body wall, then increases in 5-HT in the hemolymph should occur in animals that were sensitized by noxious stimulation. Therefore, siphon withdrawal and changes in levels of 5-HT in the hemolymph were measured in the same animal. Unilateral sensitization of the siphon withdrawal reflex was observed in animals $24 \mathrm{hr}$ after electrical stimulation. The side of the animals that was trained showed a significant $152 \pm 22 \%(n=8$; SEM $)$ increase in the duration of siphon withdrawal compared to the control side, which showed no sensitization $(2 \pm 3 \%$ increase; $t=6.96$; $\mathrm{df}=7$; $p<0.001)$. In these same animals, 5-HT in the hemolymph significantly increased $20 \pm 4 \% 24 \mathrm{hr}$ after electrical stimulation $(t=4.6 ; \mathrm{df}=7 ; p<0.005)$. Furthermore, control animals that received no electrical stimulation showed no long-term behavioral sensitization as measured by siphon withdrawal duration $(9 \pm 6 \%$ increase, $n=5)$ and no change in levels of 5-HT in the hemolymph $(0 \pm 7 \%)$. The magnitude of the change in duration of siphon withdrawal was significantly correlated with the magnitude of the change in 5-HT in the hemolymph (Fig. $5 ; r=0.66$; $\mathrm{df}=7 ; p=0.05)$. This result indicates that changes in the levels of 5-HT in the hemolymph are related to changes in the siphonwithdrawal reflex, and thus may be involved in behavioral sensitization. In these experiments in which siphon withdrawal and 5-HT were both determined, it is unlikely that the behavioral testing itself led to the increase in 5-HT in the hemolymph since levels of 5-HT in the hemolymph did not increase in control animals which received no electrical stimulation (Fig. 5), and electrical stimulation alone led to a similar increase in 5-HT when no behavioral measurements were made (Fig. 4).

The increase we observed in 5-HT in the hemolymph $24 \mathrm{hr}$ after training could be caused by several factors. An initial increase of 5-HT could lead to a long-lasting elevation if 5-HT in the hemolymph was stable and the skin of the animal was imper-

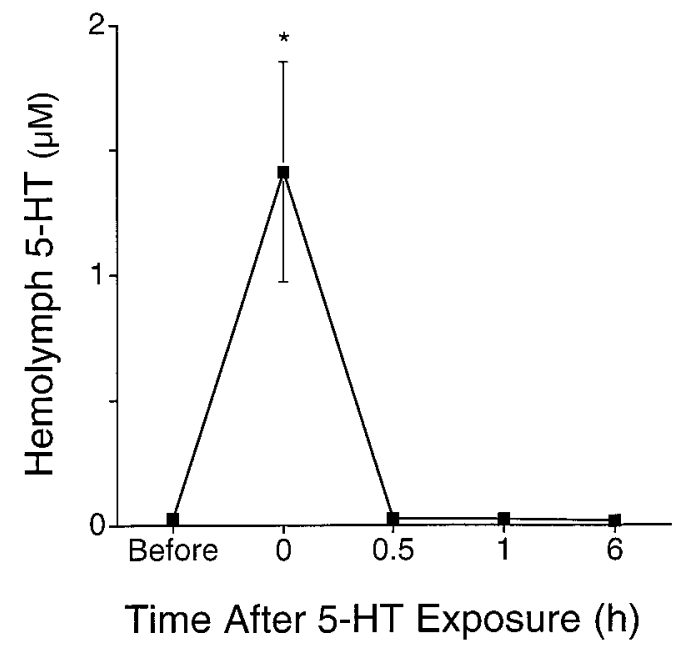

Figure 6. Disappearance of 5-HT from the hemolymph. Concentration of 5-HT in the hemolymph is plotted as a function of different times before and after an in vivo exposure to 5-HT (Alberini et al., 1994). Hemolymph was sampled from sensitized animals just before, immediately after, and then $0.5,1$, and $6 \mathrm{hr}$ after a $0.5 \mathrm{hr}$ treatment of $250 \mu \mathrm{M}$ 5-HT. The in vivo treatment increased the concentration of 5-HT to $1.4 \pm$ $0.4 \mu \mathrm{M}$. By $0.5 \mathrm{hr}$ after the end of the treatment, levels of 5-HT returned to baseline values. Three to four animals were sampled at each time point. Animals were only sampled once. No significant differences were observed for samples collected $0.5 \mathrm{hr}$ after treatment or later when compared to baseline values.

meable to 5-HT. To ascertain whether long-term increases in 5-HT could be caused by its persistence in the hemolymph once it was elevated in sensitized animals, we investigated how long an increase in 5-HT in the hemolymph would persist. Sensitized animals were used in this experiment because the turnover of 5-HT or its diffusion through the skin might be altered by the training procedure. Animals were sensitized and then bathed in $250 \mu \mathrm{M} 5$-HT for $0.5 \mathrm{hr}$ to elevate 5-HT in the hemolymph (Alberini et al., 1994). Hemolymph was sampled from individual animals before and at various times after exposure to 5-HT. Immediately after this treatment, 5 -HT in the hemolymph was $\sim 1.4 \pm 0.4 \mu \mathrm{M}$ (Fig. $6 ; F=36.9 ; \mathrm{df}=16 ; p<0.0001 ; \mathrm{MSD}=188$ $\mu \mathrm{M} ; p<0.05)$. By $0.5 \mathrm{hr}$ after the end of treatment, 5-HT had returned to baseline values (Fig. 6). Similar results were obtained when this experiment was performed in nonsensitized animals and when smaller changes in hemolymph 5-HT were produced (data not shown). It is possible that the clearance mechanisms used for micromolar concentrations of 5-HT differ from those used at the nanomolar concentration. If this is so, there should be a rapid decrease in levels of 5-HT in the hemolymph from micromolar to nanomolar, followed by a slower decay back to baseline. This pattern was not seen in our data. Levels of 5-HT returned to baseline within $0.5 \mathrm{hr}$. This suggests that there is no "slow" decay for 5-HT. Therefore, since increases in 5-HT in the hemolymph produced by in vivo exposure to 5-HT lasted relatively brief periods of time, long-term sensitization training appears to lead to a prolonged release of 5-HT from serotonergic neurons or other sources that lasts at least for $24 \mathrm{hr}$.

The long-lasting increase in 5-HT in the hemolymph could be produced by mechanisms similar to those responsible for producing long-term memory in Aplysia and other organisms. New protein synthesis appears to be a general requirement during the induction phase of long-term memory (Flexner et al., 1963; Agranoff, 1967; Barondes, 1975; Agranoff et al., 1978; Davis and 


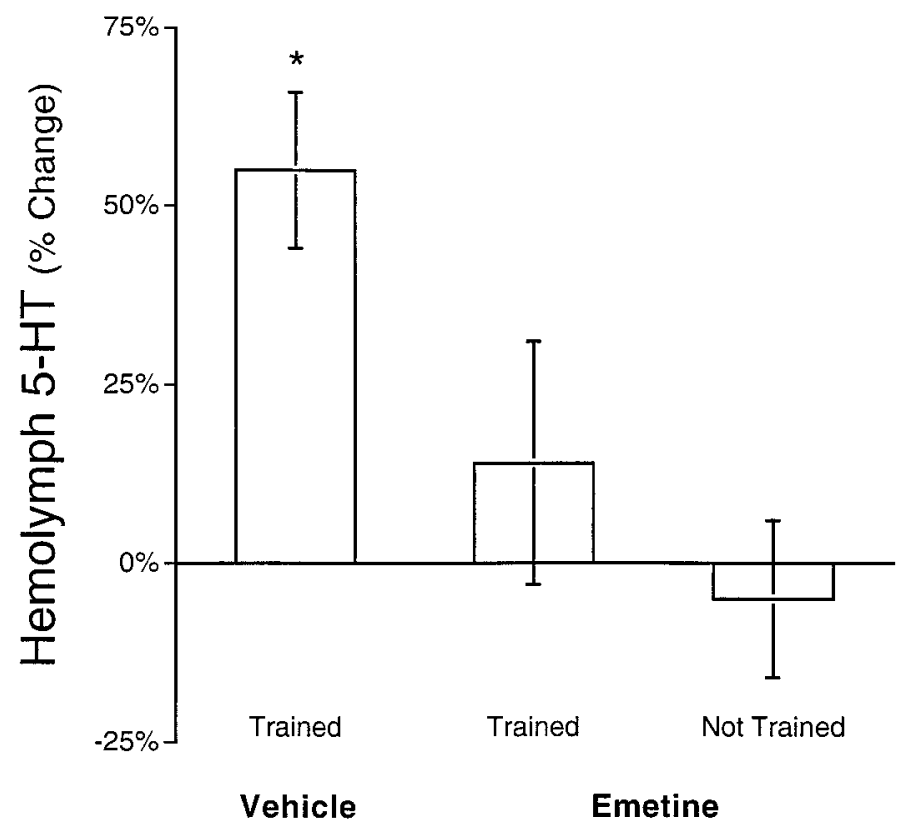

Figure 7. Inhibition of protein synthesis blocks the $24 \mathrm{hr}$ increase in hemolymph 5-HT caused by sensitization training. The level of 5-HT in the hemolymph was measured $24 \mathrm{hr}$ after sensitization training and compared to baseline values measured $1 \mathrm{hr}$ before training. Animals were injected with $1 \mathrm{ml}, 9 \mathrm{~mm}$ emetine (in BFSW with 3\% ethanol) per $140 \mathrm{gm}$ body weight $0.5 \mathrm{hr}$ before sensitization training. The control group received an injection of vehicle (BFSW with $3 \%$ ethanol) $0.5 \mathrm{hr}$ before sensitization training. There was a significant increase in 5-HT in the hemolymph of the control group $24 \mathrm{hr}$ after the end of sensitization training $(p<0.05)$. However, animals that received an injection of emetine before sensitization training did not have increased levels of hemolymph 5-HT. Also, injection of emetine alone (Not Trained group) did not alter levels of 5-HT $24 \mathrm{hr}$ later. The asterisk indicates that the control group was significantly different from the two groups that received emetine. Each group consisted of seven different animals.

Squire, 1984; Castellucci et al., 1986; Goelet et al., 1986; Milner et al., 1998). Therefore, we investigated whether the $24 \mathrm{hr}$ increase in 5-HT in the hemolymph was dependent on protein synthesis. The protein synthesis inhibitor emetine, which has been used for studies both in vivo and in vitro in Aplysia (Schwartz et al., 1971; Castellucci et al., 1986; Montarolo et al., 1986; Hegde et al., 1997; Martin et al., 1997), was injected into animals $0.5 \mathrm{hr}$ before electrical stimulation. Inhibition of protein synthesis does not appear to have effects on the neurophysiological properties of Aplysia neurons (Schwartz et al., 1971) or synaptic transmission (Castellucci et al., 1986; Montarolo et al., 1986). The concentration of emetine in the hemolymph after injection $(1 \mathrm{ml}, 9 \mathrm{~mm}$ per 150 gm body weight) was estimated to be $\sim 100 \mu \mathrm{M}$. The effect of emetine on protein synthesis was assayed by measuring $\left[{ }^{3} \mathrm{H}\right]$ leucine incorporation into protein in ganglia removed from Aplysia $0.5 \mathrm{hr}$ after they were injected with emetine (see Materials and Methods). Emetine injections inhibited protein synthesis by $93 \%( \pm 2 \% ; n=3)$ in the pleural-pedal ganglia and $91 \%( \pm$ $2 \% ; n=3)$ in the abdominal ganglion. Emetine blocked the increase in 5-HT in the hemolymph $24 \mathrm{hr}$ after electrical stimulation (Fig. 7; $F=5.42$; df $=20 ; p<0.02$; MSD $=24 \% ; p<0.05$ ). Furthermore, emetine injection alone did not change levels of 5-HT in the hemolymph (Fig. 7). Although other neural effects cannot be ruled out, the results suggest that blockage of the long-term increase in hemolymph 5-HT by emetine was caused by inhibition of protein synthesis.
A
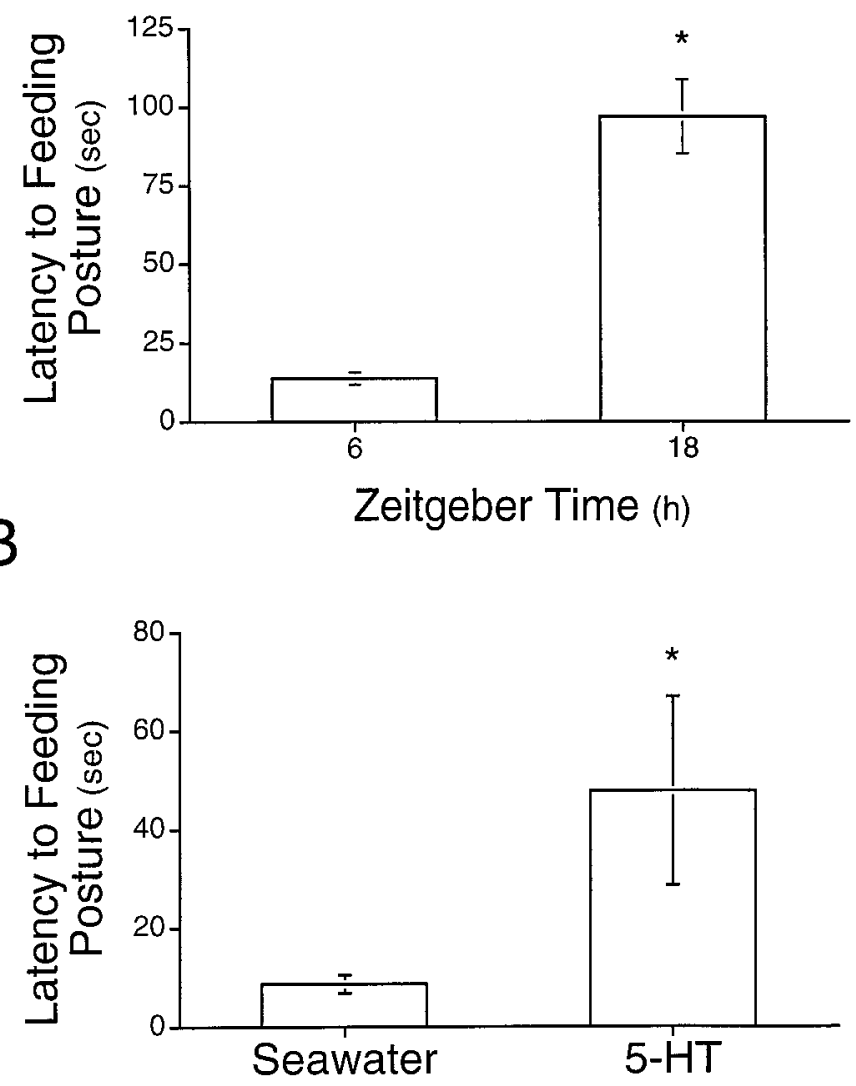

Figure 8. 5-HT in the hemolymph regulates feeding. $A$, Latency to assumption of feeding posture expressed a significant diurnal rhythm (Kupfermann, 1974). B, Injection of 5-HT into the hemocoel of Aplysia in the middle of the day (ZT6) significantly lengthened the latency to assume feeding posture. Injections were designed to elevate 5-HT in the hemolymph to levels normally seen at night. Asterisks indicate a significant $(p<0.05)$ difference relative to values at ZT6.

\section{Influence of hemolymph 5-HT on feeding}

There are many possible functional consequences of changes in the levels of 5-HT in the hemolymph (for example, see Table 1). To begin investigating functional consequences of elevations of 5-HT in the hemolymph, we examined an aspect of appetitive feeding behavior, since 5-HT has been implicated in regulation of feeding behavior (Weiss et al., 1975; Weiss et al., 1978; Kupfermann et al., 1979). Aplysia were exposed to dried seaweed, and the time required to elicit the feeding posture was measured (see Materials and Methods). Confirming Kupfermann (1974), we found that Aplysia expressed a diurnal rhythm of latency to assume feeding posture (Fig. 8A). Aplysia responded much more quickly during the day $(13.7 \pm 1.9 \mathrm{sec})$ than they did at night $(97.0 \pm 11.8 \mathrm{sec})$. This rhythm was specific for food, because stimulation of animals with filter paper failed to elicit the feeding posture at either time $(n=5$; data not shown). To investigate whether 5-HT in the hemolymph might be involved in modulating feeding latency, 5-HT was increased in the hemolymph at a time during the day (ZT6) when 5-HT was normally low. We predicted that increasing 5-HT during the day would lead to an increase in the latency to assume feeding posture, similar to what is normally observed at night when 5-HT is elevated. Experimental animals received an injection of 5-HT during the day that increased levels 
of 5 -HT in the hemolymph within 5 min to $25.8 \pm 4.9 \mathrm{~nm}$, a level normally seen at night (see Materials and Methods; Fig. 2). As predicted, animals that were injected with 5-HT had significantly longer latencies to feed than animals injected with saline (Fig. $7 B$; $U=60 ;$ df $=16 ; p<0.05)$.

\section{DISCUSSION}

This study demonstrates that environmental events that affect the state of the animal (LD cycles, sensitization training) also regulate levels of 5-HT in the hemolymph. Furthermore, levels of 5-HT in the hemolymph were significantly elevated after arrival of the animals in the laboratory relative to levels measured $3 \mathrm{~d}$ later (Fig. 1). The level of 5-HT in the hemolymph is close to threshold values reported for several physiological responses (Table 1). Therefore, the changes in 5-HT we observed, given their magnitudes and persistent nature, are probably sufficient to produce significant effects on the properties of neurons. In support of this idea, we found that elevating 5-HT in the hemolymph from a "day" level to a "night" level led to an increase in latency to assume feeding posture (Fig. 8). Our findings, taken together with those of others showing effects of injections of 5-HT on behavior (Palovcik et al., 1982; Mackey and Carew, 1983; Parsons and Pinsker, 1989), indicate that 5-HT in the hemolymph may play a humoral role and modulate the behavior of Aplysia.

Levels of 5-HT in the hemolymph could be regulated via several processes. A number of possible sites of release of 5-HT into the hemolymph exist. Electrical stimulation or training of the animal may acutely release 5-HT from synapses in the CNS or peripheral nervous system and this 5-HT may "spill over" into the hemolymph (Peretz and Estes, 1974; Tritt et al., 1983; Goldstein et al., 1984; Ono and McCaman, 1984; Kistler et al., 1985; Longley and Longley, 1986; Rathouz and Kirk, 1988; Zhang et al., 1991; Hernádi et al., 1992). Also, the eyes are surrounded by a basket of serotonergic fibers originating from the accessory optic nerve, and the blood vessels of Aplysia are highly innervated by serotonergic processes (Liebeswar et al., 1975; Takahashi et al., 1988; Alevizos et al., 1989; Skelton and Koester, 1992). Finally, hemocytes may also release 5-HT into the hemolymph (Stefano et al., 1989; Ottaviani and Cossarizza, 1990; Ottaviani et al., 1992; Levenson and Eskin, unpublished observations). Clearance of 5-HT by the kidneys or hemocytes (Goldman and Schwartz, 1977) may also contribute to the regulation of 5-HT in the hemolymph.

The possible sites of action of 5-HT in the hemolymph are diverse. In the nervous system, humoral 5-HT may exert its effects through synaptic 5-HT receptors, or perhaps through extrasynaptic 5-HT receptors located on cell bodies (Drummond et al., 1980b; Li et al., 1995; Angers et al., 1998). Humoral 5-HT would reach these sites through delivery via the open circulatory system and by penetration of the connective tissue sheath. Humoral 5-HT appears to have ready access to cell bodies, and perhaps slightly less access to the neuropil (Brunelli et al., 1976; Kaczmarek et al., 1978; Drummond et al., 1980a; Byrne et al., 1991; Emptage et al., 1996; Bunge et al., 1997).

\section{Diurnal variation of 5-HT in the hemolymph}

The diurnal rhythm of 5-HT in the hemolymph may play a role in regulating or modulating daily behaviors. In several invertebrates, 5-HT and other neurohormones have been shown to be important modulators of behavior or the neuronal circuitry underlying those behaviors (Poon, 1980; Livingstone et al., 1980; Willard, 1981; Schwarz et al., 1984; Claassen and Kammer, 1985; Marder et al., 1986; Mulloney et al., 1987; Tuersley and McCrohan, 1987; Nus- baum and Marder, 1988; Mangan et al., 1994; Malyshev et al., 1997). Feeding behavior in Aplysia undergoes daily changes (Kupfermann, 1974; Fig. $8 A$ ), and we have found that those changes correlate with the level of 5-HT in the hemolymph (Fig. $8 A$ ). Specifically, when levels of 5-HT in the hemolymph were low, latency to feed was low. When levels of 5-HT in the hemolymph were high, feeding latency was high. Moreover, when levels of 5-HT in the hemolymph were elevated to nighttime levels by injection of 5-HT during the day, latency to feed increased (Fig. $8 B$ ). These results suggest that one function of the diurnal rhythm of 5-HT in the hemolymph may be to regulate feeding behavior. Further tests of this specific idea will require examining feeding latency when levels of 5-HT in the hemolymph are lowered or 5-HT receptors are blocked in vivo during the night.

Another daily behavior that could be regulated by 5-HT in the hemolymph is locomotor activity. Injections of 5-HT increase locomotor activity (Palovcik et al., 1982; Mackey and Carew, 1983; Parsons and Pinsker, 1989; see also Adamo and Chase, 1991), and the diurnal pattern of locomotor activity peaks during the day (Lickey et al., 1977). However, the levels of 5-HT in the hemolymph are lowest during the day, when activity is highest. In the studies that examined the effects of injection of 5-HT into Aplysia, behavior was measured no more than $15 \mathrm{~min}$ after injection, and the effective concentration of 5-HT after injection was much higher than levels observed in this study. Thus, lower levels of 5-HT might have opposite effects than high doses. In addition, acute treatments may produce different effects than longer term treatments. Indeed, modulation of pituitary lactotroph prolactin secretion by endothelin-1 is either inhibitory or stimulatory depending on whether the cells are exposed to an acute or chronic treatment of dopamine, respectively (Kanyicska et al., 1995, 1997).

\section{Elevation of 5-HT caused by electrical stimulation}

A significant increase in levels of 5-HT in the hemolymph was observed in our studies during electrical stimulation that leads to sensitization (Fig. 4). This finding is the first evidence that release of 5-HT actually accompanies sensitization training in Aplysia and, as such, further suggests that 5-HT plays a role in mediating the effects of sensitization training. Moreover, the increase in siphon withdrawal duration was correlated with the magnitude of the increase in 5-HT in the hemolymph (Fig. 5). This further indicates a relationship between elevation of 5-HT in the hemolymph and sensitization.

A significant increase in 5-HT in the hemolymph also occurred 1.5 and $24 \mathrm{hr}$ after electrical stimulation (Fig. 4). The long-lasting increase in 5-HT in the hemolymph appeared to be caused by a persistent release of 5-HT from serotonergic neurons or other sources, because the half-life of 5-HT in the hemolymph was relatively short (Fig. 6). These results demonstrated that a single $1.5 \mathrm{hr}$ block of electrical stimulation led to an increase in the levels of 5-HT in the hemolymph that persisted for $24 \mathrm{hr}$. Multiple blocks of such stimulation performed over several (2-4) days leads to sensitization that persists for weeks (Pinsker et al., 1973). It would be interesting to examine the effect of multiple blocks of electrical stimulation on the duration of the increase in 5-HT to determine whether the increase in 5-HT in the hemolymph might persist even longer than a day.

Formation of long-term memory in Aplysia and many other organisms requires protein synthesis during the induction phase of learning (Davis and Squire, 1984; Goelet et al., 1986; Milner et al., 1998). Similarly, many of the long-lasting changes in the 
Aplysia nervous system believed to be responsible for memory have been shown to be dependent on protein synthesis (Castellucci et al., 1986; Montarolo et al., 1986; Manseau et al., 1998; Bailey et al., 1992; O'Leary et al., 1995). Like these other processes, the $24 \mathrm{hr}$ increase in 5-HT in the hemolymph induced by sensitization training was blocked via inhibition of protein synthesis (Fig. 7). The similarities in time course and requirement of new protein synthesis between changes in levels of 5-HT in the hemolymph and long-term changes responsible for memory indicate that changes in 5-HT in the hemolymph might be one of the constellation of factors that contribute to various forms of longterm memory in Aplysia. Moreover, some of the same molecular mechanisms (Abel et al., 1998) involved in the formation of long-term memory produced by sensitization training may also be involved in producing the long-lasting increase in 5-HT in the hemolymph.

What is the role of the elevated levels of 5-HT in the hemolymph or the proposed persistent increase in activity of serotonergic neurons produced by sensitization training? An increase in circulating 5-HT produced by training may increase the sensitivity of peripheral mechanoreceptors and photoreceptors (Eskin and Maresh, 1982; Billy and Walters, 1989). Elevations of 5-HT may also elevate heart rate and increase vascular tone (Liebeswar et al., 1975; Krontiris-Litowitz et al., 1989). Nonessential behaviors may be inhibited by increases in circulating 5-HT. Humoral effects of 5-HT could contribute to, or even cause in some cases the behavioral sensitization seen immediately after sensitization training and $24 \mathrm{hr}$ later. It is important to note that in some instances, including the present study, electrical stimulation leads to long-term unilateral sensitization (Scholz and Byrne, 1987; Goldsmith and Byrne, 1993; Cleary et al., 1998). In these cases, humoral 5-HT could not contribute to the induction of sensitization unless the unilateral sensitization was produced by an associative mechanism involving humoral 5-HT, and neural activity on the side of the animal that was trained.

The increase in humoral 5-HT during training also could strengthen memory formation by helping to induce facilitation of the sensorimotor synapse and interneuronal connections (Bailey et al., 1981; Trudeau and Castellucci, 1993; Xu et al., 1995). This possible role of an increase in humoral 5-HT would be similar to the proposed enhancing role of catecholamines in memory formation of mammals (for review, see McGaugh et al., 1996). In the rat, elevation of epinephrine in the plasma during aversive training enhances memory acquisition (McCarty and Gold, 1981; Galvez et al., 1996).

5-HT was also elevated in the hemolymph 1.5 and $24 \mathrm{hr}$ after sensitization training of Aplysia. The prolonged elevation of 5-HT or the activation of neurons causing the prolonged elevation of 5-HT may aid in the induction of facilitation and participate in the mechanism maintaining facilitation for long periods of time. Thus, the prolonged release of 5-HT might be part of the "memory" for long-term sensitization. Moreover, the prolonged release of 5-HT might potentiate future training as epinephrine does in the rat, and be relevant for additional training that lasts for several days. Subsequent training sessions of Aplysia on following days would be done in the presence of heightened activity of serotonergic neurons or elevated 5-HT in the hemolymph. Prolonged increases in neuronal activity and levels of humoral factors present a possible mechanism for strengthening formation of memories when learning takes place over a relatively long time scale, such as days or weeks.

Our findings raise the possibility that 5-HT may act as a neuroendocrine molecule in the hemolymph to regulate the behavioral state of Aplysia. Humoral 5-HT may directly mediate some events, whereas it may act as a modulator in other cases. The acute changes in levels of 5-HT in the hemolymph may have different roles than the chronic presence of 5-HT in the hemolymph (Kanyicska et al., 1995, 1997). It is also possible that 5-HT released at synapses because of persistent neural activity induced by sensitization training may be more or less important than humoral 5-HT. Ultimately, it will be important to determine the role of 5-HT in the hemolymph and distinguish its humoral role from its neurotransmitter role. It will also be important to determine the site of release of 5-HT into the hemolymph and the mechanisms responsible for persistence of 5-HT in the hemolymph after sensitization training.

\section{REFERENCES}

Abel T, Martin KC, Bartsch D, Kandel ER (1998) Memory suppressor genes: Inhibitory constraints on the storage of long-term memory. Science 279:338-341.

Adamo SA, Chase R (1991) "Central arousal" and sexual responsiveness in the snail, Helix aspersa. Behav Neural Biol 55:194-213.

Agranoff BW, Davis RE, Casola L, Lim R (1967) Actinomycin D blocks formation of memory of shock avoidance in goldfish. Science 158:16001601.

Agranoff BW, Burrell HR, Dokas LA, Springer AD (1978) Progress in biochemical approaches to learning and memory. In: Psychopharmacology: a generation of progress (Lipton MA, Di Mascio A, Killam KF, eds), pp 623-635. New York: Raven.

Alberini CM, Ghirardi M, Metz R, Kandel ER (1994) C/EBP is an immediate-early gene required for the consolidation of long-term facilitation in Aplysia. Cell 76:1099-1114.

Alevizos A, Bailey CH, Chen M, Koester J (1989) Innervation of vascular and cardiac muscle of Aplysia by multimodal motoneuron L7. J Neurophysiol 61:1053-1063.

Angers A, Storozhuk MV, Duchaine T, Castellucci VF, DesGroseillers L (1998) Cloning and functional expression of an Aplysia 5-HT receptor negatively coupled to adenylate cyclase. J Neurosci 18:5586-5593.

Bailey CH, Hawkins RD, Chen MC, Kandel ER (1981) Interneurons involved in mediation and modulation of gill-withdrawal reflex in Aplysia. IV. Morphological basis of presynaptic facilitation. J Neurophysiol 45:340-360.

Bailey CH, Montarolo P, Chen M, Kandel ER, Schacher S (1992) Inhibitors of protein and RNA synthesis block structural changes that accompany long-term heterosynaptic plasticity in Aplysia. Neuron 9:749758.

Barondes SH (1975) Protein synthesis dependent and protein synthesis independent memory storage processes. In: Short-term memory (Deutsch D, Deutsch JA, eds), pp 379-390. New York: Academic.

Bernier L, Castellucci VF, Kandel ER, Schwartz JH (1982) Facilitatory transmitter causes a selective and prolonged increase in adenosine $3^{\prime}: 5^{\prime}$-monophosphate in sensory neurons mediating the gill and siphon withdrawal reflex in Aplysia. J Neurosci 2:1682-1691.

Billy AJ, Walters ET (1989) Modulation of mechanosensory threshold in Aplysia by serotonin, small cardioactive peptide ${ }_{\mathrm{B}}\left(\mathrm{SCP}_{\mathrm{B}}\right)$, FMRFamide, acetylcholine, and dopamine. Neurosci Lett 105:200-204.

Brunelli M, Castellucci V, Kandel ER (1976) Synaptic facilitation and behavioral sensitization in Aplysia: possible role of serotonin and cyclic AMP. Science 194:1178-1181.

Bunge SA, Mauelshagen J, Carew TJ (1997) Reversal of relative thresholds for synaptic facilitation and increased excitability induced by serotonin and tail nerve stimulation in Aplysia sensory neurons. Neurobiol Learn Mem 67:259-263.

Byrne JH, Baxter DA, Buonomano DV, Cleary LJ, Eskin A, Goldsmith JR, McClendon E, Nazif FA, Noel F, Scholz KP (1991) Neural and molecular bases of nonassociative and associative learning in Aplysia. Ann NY Acad Sci 627:124-149.

Cardot J (1971) Variations saisonnières de la 5-hydroxytryptamine dans les tissus nerveux et cardiaque chex la mollusque Helix pomatia. C R Seances Soc Biol Fil 165:338-341.

Castellucci VF, Frost WN, Goelet P, Montarolo PG, Schacher S, Morgan JA, Blumenfeld H, Kandel ER (1986) Cell and molecular analysis of long-term sensitization in Aplysia. J Physiol (Paris) 81:349-357. 
Claassen D, Kammer A (1985) Effects of octopamine, dopamine, and serotonin on production of flight motor output by throacic ganglia of Manduca sexta. J Neurobiol 17:1-14.

Cleary LJ, Lee WL, Byrne JH (1998) Cellular correlates of long-term sensitization in Aplysia. J Neurosci 18:5988-5998.

Colwell CS (1990) Light and serotonin interact in affecting the circadian system of Aplysia. J Comp Physiol [A] 167:841-845.

Cooper BF, Krontiris-Litowitz JK, Walters ET (1989) Humoral factors released during trauma of Aplysia body wall II. Effects of possible mediators. J Comp Physiol [B] 159:225-235.

Corrent G, Eskin A (1982) Transmitterlike action of serotonin in phase shifting a rhythm from the Aplysia eye. Am J Physiol 242:R333-R338.

Corrent G, Eskin A, Kay I (1982) Entrainment of the circadian rhythm from the eye of Aplysia: role of serotonin. Am J Physiol 242:R326-R332.

Davis HP, Squire LR (1984) Protein synthesis and memory: a review. Psychol Bull 96:518-559.

Deguchi T, Axelrod J (1972) Control of circadian change in serotonin $N$-acetyltransferase activity in the pineal organ by the $\beta$-adrenergic receptor. Proc Natl Acad Sci USA 69:2547-2550.

Drummond AH, Benson JA, Levitan IB (1980a) Serotonin-induced hyperpolarization of an identified Aplysia neuron is mediated by cyclic AMP. Proc Natl Acad Sci USA 77:5013-5017.

Drummond AH, Bucher F, Levitan IB (1980b) Distribution of serotonin and dopamine receptors in Aplysia tissues: analysis by [ $\left.{ }^{3} \mathrm{H}\right] \mathrm{LSD}$ binding and adenylate cyclase stimulation. Brain Res 184:163-177.

Edwards DH, Kravitz EA (1997) Serotonin, social status and aggression. Curr Opin Neurobiol 7:812-819.

Emptage NJ, Carew TJ (1993) Long-term synaptic facilitation in the absence of short-term facilitation in Aplysia neurons. Science 262:253-256.

Emptage NJ, Mauelshagen J, Carew TJ (1996) Threshold serotonin concentration required to produce synaptic facilitation differs for depressed and nondepressed synapses in Aplsyia sensory neurons. J Neurophysiol 75:843-854.

Eskin A, Maresh RD (1982) Serotonin or electrical optic nerve stimulation increases the photosensitivity of the Aplysia eye. Comp Biochem Physiol 73C:27-31.

Flexner JB, Flexner LB, Stellar E (1963) Memory in mice as affected by intracerebral puromycin. Science 141:57-59.

Galvez R, Mesches MH, McGaugh JL (1996) Norepinephrine release in the amygdala in response to footshock stimulation. Neurobiol Learn Mem 66:253-257.

Glanzman DL, Mackey SL, Hawkins RD, Dyke AM, Lloyd PE, Kandel ER (1989) Depletion of serotonin in the nervous system of Aplysia reduces the behavioral enhancement of gill withdrawal as well as the heterosynaptic facilitation produced by tail shock. J Neurosci 9:4200-4213.

Goelet P, Castellucci VF, Schacher S, Kandel ER (1986) The long and short of long term memory-a molecular framework. Nature 322:419-422.

Goldman JE, Schwartz JH (1977) Metabolism of $\left[{ }^{3} \mathrm{H}\right]$ serotonin in the marine mollusc, Aplysia californica. Brain Res 136:77-88.

Goldsmith JR, Byrne JH (1993) Bag cell extract inhibits tail-siphon withdrawal reflex, suppresses long-term but not short-term sensitization, and attenuates sensory-to-motor neuron synapses in Aplysia. J Neurosci 13:1688-1700.

Goldstein R, Kistler HB, Steinbusch HW, Schwartz JH (1984) Distribution of serotonin-immunoreactivity in juvenile Aplysia. Neuroscience 11:535-547.

Hammer M, Cleary LJ, Byrne JH (1989) Serotonin acts in the synaptic region of sensory neurons in Aplysia to enhance transmitter release. Neurosci Lett 104:235-240.

Hegde AN, Inokuchi K, Pei W, Casadio A, Ghirardi M, Chain DG, Martin KC, Kandel ER, Schwartz JH (1997) Ubiquitin c-terminal hydrolase is an immediate-early gene essential for long-term facilitation in Aplysia. Cell 89:115-126.

Hernádi L, Rózsa KS-, Jahan-Parwar B, Carpenter DO (1992) A topography and ultrastructural characterization of in vivo 5,7dihydroxytryptamine-labeled serotonin-containing neurons in the central nervous system of Aplysia californica. Cell Mol Neurobiol 12:317-325.

Jacklet JW (1969) Circadian rhythm of optic nerve impulses recorded in darkness from isolated eye of Aplysia. Science 164:562-563.

Kaczmarek LK, Jennings K, Strumwasser F (1978) Neurotransmitter modulation, phosphodiesterase inhibitor effects, and cyclic AMP correlates of afterdischarge in peptidergic neurites. Proc Natl Acad Sci USA 75:5200-5204.

Kanyicska B, Livingstone JD, Freeman ME (1995) Long term exposure to dopamine reverses the inhibitory effect of endothelin-1 on prolactin secretion. Endocrinology 136:990-994.

Kanyicska B, Freeman ME, Dryer SE (1997) Endothelin activates largeconductance $\mathrm{K}^{+}$channels in rat lactotrophs: reversal by long-term exposure to dopamine agonist. Endocrinology 138:3141-3153.

Kistler HB, Hawkins RD, Koester J, Steinbusch HW, Kandel ER, Schwartz JH (1985) Distribution of serotonin-immunoreactive cell bodies and processes in the abdominal ganglion of mature Aplysia. J Neurosci 5:72-80.

Klein DC, Weller JL (1972) Rapid light-induced decrease in pineal serotonin $N$-acetyltransferase activity. Science 177:532-533.

Klein M, Camardo J, Kandel ER (1982) Serotonin modulates a specific potassium current in the sensory neurons that show presynaptic facilitation in Aplysia. Proc Natl Acad Sci USA 79:5713-5717.

Krontiris-Litowitz JK, Cooper BF, Walters ET (1989) Humoral factors released during trauma of Aplysia body wall: I. Body wall contraction, cardiac modulation, and central reflex suppression. J Comp Physiol [B] 159:211-223

Kupfermann I (1974) Feeding behavior in Aplysia: a simple system for the study of motivation. Behav Biol 10:1-26.

Kupfermann I, Weiss KR (1982) Activity of an identified serotonergic neuron in free moving Aplysia correlates with behavioral arousal. Brain Res 241:334-337.

Kupfermann I, Cohen JL, Mandelbaum DE, Schonberg M, Susswein AJ, Weiss KR (1979) Functional role of serotonergic neuromodulation in Aplysia. Fed Proc 38:2095-2102.

Laurienti PJ, Blankenship JE (1997) Serotonergic modulation of a voltage-gated calcium current in parapodial swim muscle from Aplysia brasiliana. J Neurophysiol 77:496-502.

Li XC, Giot JF, Kuhl D, Hen R, Kandel ER (1995) Cloning and characterization of two related serotonergic receptors from the brain and the reproductive system of Aplysia that activate phospholipase C. J Neurosci 15:7585-7591.

Lickey ME, Wozniak JA, Block GD, Hudson DJ, Augter GK (1977) The consequences of eye removal for the circadian rhythm of behavioral activity in Aplysia. J Comp Physiol 118:121-143.

Liebeswar G, Goldman JE, Koester J, Mayeri E (1975) Neural control of circulation in Aplysia III. Neurotransmitters. J Neurophysiol 38:767-779

Livingstone MS, Harris-Warrick RM, Kravitz EA (1980) Serotonin and octopamine produce opposite postures in lobsters. Science 208:76-79.

Longley RD, Longley AJ (1986) Serotonin immunoreactivity of neurons in the gastropod Aplysia californica. J Neurobiol 17:339-358.

Mackey S, Carew TJ (1983) Locomotion in Aplysia: triggering by serotonin and modulation by bag cell extract. J Neurosci 3:1469-1477.

Malyshev A, Bravarenko N, Balaban P (1997) Dependence of synaptic facilitation postsynaptically induced in snail neurones on season and serotonin level. NeuroReport 8:1179-1182.

Mangan PS, Curran GA, Hurney CA, Friesen WO (1994) Modulation of swimming behavior in the medicinal leech. III. Control of cellular properties in motor neurons by serotonin. J Comp Physiol [A] 175:709-722.

Manseau F, Sossin WS, Castellucci VF (1998) Long-term changes in excitability induced by protein kinase C activation in Aplysia sensory neurons. J Neurophysiol 79:1210-1218.

Marder E, Hooper SL, Siwicki KK (1986) Modulatory action and distribution of the neuropeptide proctolin in the crustacean stomatogastric nervous system. J Comp Neurol 243:454-467.

Martin KC, Casadio A, Zhu H, Yaping E, Rose JC, Chen M, Bailey CH, Kandel ER (1997) Synapse-specific, long-term facilitation of Aplysia sensory to motor synapses: a function for local protein synthesis in memory storage. Cell 91:927-938.

McCarty R, Gold PE (1981) Plasma catecholamines: effects of footshock level and hormonal modulators of memory storage. Horm Behav 15:168-182.

McGaugh JL, Cahill L, Roozendaal B (1996) Involvement of the amygdala in memory storage: interaction with other brain systems. Proc Natl Acad Sci USA 93:13508-13514.

McPherson DR, Blankenship JE (1991) Neuronal control of swimming in Aplysia brasiliana. III. Serotonergic modulatory neurons. J Neurophysiol 66:1366-1379. 
McPherson DR, Blankenship JE (1992) Neuronal modulation of foot and body-wall contractions in Aplysia californica. J Neurophysiol 67:23-28.

Milner B, Squire LR, Kandel ER (1998) Cognitive neuroscience and the study of memory. Neuron 20:445-468.

Montarolo PG, Goelet P, Castellucci VF, Morgan J, Kandel ER, Schacher S (1986) A critical period for macromolecular synthesis in long-term heterosynaptic facilitation in Aplysia. Science 234:1249-1254.

Moore RY, Klein DC (1974) Visual pathways and the central neural control of a circadian rhythm in pineal serotonin $N$-acetyltransferase activity. Brain Res 71:17-33.

Mulloney B, Acevedo L, Bradbury A (1987) Modulation of the crayfish swimmeret rhythm by octopamine and the neuropeptide proctolin. J Neurophysiol 58:584-597.

Nusbaum MP, Marder E (1988) A neuronal role for a crustacean red pigment concentrating hormone-like peptide: neuromodulation of the pyloric rhythm in the crab, Cancer borealis. J Exp Biol 135:165-181.

O'Leary FA, Byrne JH, Cleary LJ (1995) Long-term structural remodeling in Aplysia sensory neurons requires de novo protein synthesis during a critical time period. J Neurosci 15:3519-3525.

Ono JK, McCaman RE (1984) Immunocyotchemical localization and direct assays of serotonin-containing neurons in Aplysia. Neuroscience 11:549-560.

Ottaviani E, Cossarizza A (1990) Immunocytochemical evidence of vertebrate bioactive peptide-like molecules in the immuno cell types of the freshwater snail Planorbarius corneus (L.) (gastropoda, pulmonata). FEBS Lett 267:250-252.

Ottaviani E, Franchini A, Fontanili P (1992) The presence of immunoreactive vertebrate bioactive peptide substances in hemocytes of the freshwater snail Viviparus ater. Cell Mol Neurobiol 12:455-462.

Palovcik RA, Basberg BA, Ram JL (1982) Behavioral state changes induced in Pleurobranchaea and Aplysia by serotonin. Behav Neural Biol 35:383-394.

Parsons DW, Pinsker HM (1989) Swimming in Aplysia brasiliana: behavioral and cellular effects of serotonin. J Neurophysiol 62:1163-1176.

Peretz B, Estes J (1974) Histology and histochemistry of the peripheral neural plexus in the Aplysia gill. J Neurobiol 5:3-19.

Pinsker HM, Hening WA, Carew TJ, Kandel ER (1973) Long-term sensitization of a defensive withdrawal reflex in Aplysia. Science 182:1039-1042.

Poon M (1980) Induction of swimming in lamprey by L-DOPA and amino acids. J Comp Physiol 136:337-344.

Raju U, Koumenis C, Nunez-Regueiro M, Eskin A (1991) Alteration of the phase and period of a circadian oscillator by a reversible transcription inhibitor. Science 253:673-675.

Rathouz MM, Kirk MD (1988) Localization of catecholamines in the buccal ganglia of Aplysia californica. Brain Res 458:170-175.

Rosen SC, Kupfermann I, Goldstein RS, Weiss KR (1983) Lesion of a serotonergic modulatory neuron in Aplysia produces a specific defect in feeding behavior. Brain Res 260:151-155.

Sawada M, Ichinose M, Ito I, Maeno T, McAdoo DJ (1984) Effects of 5-hydroxytryptamine on membrane potential, contractility, accumulation of cyclic AMP, and $\mathrm{Ca}^{2+}$ movements in anterior aorta and ventricle of Aplysia. J Neurophysiol 51:361-374.
Schacher S, Montarolo P, Kandel ER (1990) Selective short- and longterm effects of serotonin, small cardioactive peptide, and tetanic stimulation on sensorimotor synapses of Aplysia in culture. J Neurosci 10:3286-3294.

Scholz KP, Byrne JH (1987) Long-term sensitization in Aplysia: Biophysical correlates in tail sensory neurons. Science 235:685-687.

Schwartz JH, Castellucci VF, Kandel ER (1971) Functioning of identified neurons and synapses in abdominal ganglion of Aplysia in absence of protein synthesis. J Neurophysiol 34:939-953.

Schwarz TL, Lee GM-H, Siwicki KK, Standaert DG, Kravitz EA (1984) Proctolin in the lobster: the distribution, release and chemical characterization of a likely neurohormone. J Neurosci 4:1300-1312.

Skelton ME, Koester J (1992) The morphology, innervation and neural control of the anterior arterial system of Aplysia californica. J Comp Physiol [A] 171:141-155.

Sokal RR, Rohlf FJ (1995) Biometry. New York: Freeman.

Stefano GB, Zhao X, Bailey D, Metlay M, Leung MK (1989) High affinity dopamine binding to mouse thymocytes and Mytilus edulis (bivalvia) hemocytes. J Neuroimmunol 21:67-74.

Strumwasser F (1973) Neural and humoral factors in the temporal organization of behavior. Physiologist 16:9-42.

Takahashi JS, Nelson DE, Eskin A (1988) Immunocytochemical localization of serotonergic fibers innervating the ocular circadian system of Aplysia. Neuroscience 28:139-147.

Tritt SH, Lowe IP, Byrne JH (1983) A modification of the glyoxylic acid induced histofluorescence technique for demonstration of catecholamines and serotonin in tissues of Aplysia californica. Brain Res 259:159-162.

Trudeau LE, Castellucci VF (1993) Sensitization of the gill and siphon withdrawal reflex of Aplysia: multiple sites of change in the neuronal network. J Neurophysiol 70:1210-1220.

Tuersley M, McCrohan C (1987) Serotonergic modulation of patterned motor output in Lymnaea stagnalis. J Exp Biol 135:473-486.

Walters ET, Byrne JH, Carew TJ, Kandel ER (1983) Mechanoafferent neurons innervating tail of Aplysia. II. Modulation by sensitizing stimulation. J Neurophysiol 50:1543-59.

Weiss KR, Cohen J, Kupfermann I (1975) Potentiation of muscle contraction: a possible modulatory function of an identified serotonergic cell in Aplysia. Brain Res 99:381-386.

Weiss KR, Cohen JL, Kupfermann I (1978) Modulatory control of buccal musculature by a serotonergic neuron (metacerebral cell) in Aplysia. J Neurophysiol 41:181-203.

Willard A (1981) Effects of serotonin on the generation of the motor program for swimming by the medicinal leech. J Neurosci 1:936-944.

Xu Y, Pieroni JP, Cleary LJ, Byrne JH (1995) Modulation of an inhibitory interneuron in the neural circuitry for the tail withdrawal reflex of Aplysia. J Neurophysiol 73:1313-1318.

Zhang F, Endo S, Cleary LJ, Eskin A, Byrne JH (1997) Role of transforming growth factor- $\beta$ in long-term synaptic facilitation in Aplysia. Science 275:1318-1320.

Zhang ZS, Fang B, Marshak DW, Byrne JH, Cleary LJ (1991) Serotoninergic varicosities make synaptic contacts with pleural sensory neurons of Aplysia. J Comp Neurol 311:259-270. 